\title{
In silico, Synthesis and Biological Investigations of Pyrrolo[3,4-C]Pyrrole Hydroxamic Acid Derivatives as Potential Anticancer Agents
}

\author{
Luis Bahena, ${ }^{2}$ Carlos Cervantes, ${ }^{1}$ Karla J Soto-Arredondo, ${ }^{2}$ Minerva Martínez-Alfaro, ${ }^{2}$ Natanael Zarco, ${ }^{2}$ \\ Marco A. García-Revilla, ${ }^{1}$ Yolanda Alcaraz-Contreras, ${ }^{2}$ Lourdes Palma Tirado, ${ }^{3}$ Miguel A. Vázquez, ${ }^{1}$ and \\ Juvencio Robles ${ }^{2, *}$ \\ ${ }^{1}$ Departamento de Química, División de Ciencias Naturales y Exactas, Universidad de Guanajuato, Noria Alta S/N, C. P. 36050, \\ Guanajuato, México. \\ ${ }^{2}$ Departamento de Farmacia, División de Ciencias Naturales y Exactas, Universidad de Guanajuato, Noria Alta S/N, C. P. 36050 , \\ Guanajuato, México. \\ 3 UNAM. Instituto de Neurobiología, Boulevard Juriquilla 3001, Querétaro, C. P. 76230, México. \\ * Corresponding author: phone and fax:+52-4737320006 ext.8120, email: roblesi@ugto.mx
}

Received March 13 ${ }^{\text {th }}$, 2017; Accepted July 11 ${ }^{\text {th }}, 2017$

\begin{abstract}
Based in a general structural pharmacophore model of suberoylanilide hydroxamic acid (commercially known as Vorinostat $($ )), we synthesized a series of new pyrrolo[3,4-c]pyrrole hydroxamic acid derivatives, 9a-c, to be tested as candidates for anti-cancer drugs. The evaluation of their possible biological activity was assessed in two ways: a) computational characterization from molecular calculations and quantum reactivity descriptors and b) biological assays. Molecular docking and density functional theory calculations were performed to assess the binding properties of our newly synthesized pyrrolo[3,4-c] pyrrole hydroxamic acid derivatives, employing as the biological target the histone deacetylase isoforms available in the protein data bank. Furthermore, to characterize the effect of changing the functional groups that we varied while designing our drug model, and to improve the assessment of the binding energy, conceptual density functional theory reactivity descriptors were calculated to rationalize the capability of the new drugs to interact with the histones active site. Our findings show that the newly synthesized derivative, 9c, display the best energetic coupling with the biological target and the more favorable values of the density functional theory descriptors to interact with the active site. The biological assay of the anti-cancer drug candidates was done using three different techniques: i) anti-proliferative activity on two breast cancer cell lines; ii) Histone $\mathrm{H} 3$ acetylation; and iii) DNA damage. Docking studies were performed on histone deacetylase enzymes. The biological function of these enzymes is the deacetylation of histones. We analyze the level of histone acetylation in two cell lines. The computational findings are in good agreement with the biological evaluation. Our main contribution is that one of our newly synthesized derivatives, $\mathbf{9 c}$, performs better than the commercial reference suberoylanilide hydroxamic acid.
\end{abstract}

Keywords: Molecular docking studies; DFT; pyrrolo[3,4-c]pyrrole hydroxamic acid; synthesis; antiproliferative activity; HDAC; biological assays.
Resumen: Basados en el modelo farmacofórico del ácido suberoilanilida hidroxámico (comercialmente conocido Vorinostat $(\mathrm{C})$, sintetizamos una serie de nuevos derivados de ácidos hidroxámicos pirrolo[3,4-c] pirrol, 9a-c, para ser evaluados como candidatos a fármacos anticancerígenos. La evaluación de su posible actividad biológica se hizo desde dos enfoques, a) caracterización computacional mediante acoplamientos moleculares y el cálculo de descriptores cuánticos de reactividad, y b) ensayos biológicos. Los cálculos de acoplamientos moleculares y de funcionales de la densidad fueron realizados para evaluar la capacidad de unión de los nuevos derivados de ácidos hidroxámicos pirrolo[3,4-c] pirrol, con el blanco biológico de las isoformas de las desacetilasas de histonas utilizadas y que fueron obtenidas del protein data bank. Además, para entender el efecto del cambio de grupos funcionales en el diseño de nuestro modelo de fármaco, y para incrementar la energía de unión, se calcularon descriptores de reactividad de la teoría de funcionales de la densidad conceptual, para racionalizar la capacidad de las nuevas moléculas de acoplarse al sitio active de las histonas. Encontramos que la nueva molécula sintetizada 9c, presenta el mejor acoplamiento energético con el blanco biológico y los mejores valores de los descriptores de funcionales de la densidad para interactuar con el sitio activo. Los ensayos biológicos de la actividad anticancerígena de las moléculas candidatos a fármacos se llevó a cabo usando tres técnicas distintas: i) actividad antiproliferativa en dos líneas celulares de cáncer de mama, ii) acetilación de la histona H3 y iii) daño al ADN. Los estudios de acoplamientos moleculares se realizaron en enzimas histonas desacetilasas. La función biológica de estas enzimas es la desacetilación de las histonas. El nivel de acetilación de histonas se analizó en dos líneas celulares. Los resultados computacionales están en buen acuerdo con los resultados de la evaluación biológica. La principal contribución de este trabajo es que una de las nuevas moléculas sintetizadas, $9 \mathbf{c}$, presenta mejor actividad que el fármaco comercial de referencia ácido hidroxámico suberoilanilida.

Palabras Clave: Acoplamientos moleculares, DFT, ácido hidroxámico pirrolo [3,4-c]pirrol; síntesis; actividad antiproliferativa; HDAC; evaluación biológica. 


\section{Introduction}

Inhibitors of histone deacetylase (HDACs) are an important and relatively new class of potential drugs for the treatment of hyper proliferative diseases, as is the case of cancer $[1,2,3]$. This class of molecules bind directly to the HDAC active site and block substrate access, causing an accumulation of acetylated-histone. Suberoylanilide hydroxamic acid, (SAHA), commercially known as Vorinostat (C), is a drug used for the treatment of advanced cutaneous T-cell lymphoma [4]. SAHA inhibits histone deacetylases classes I, II and IV involved in the deacetylation of core histones. In addition, histone acetylation interferes with the effects of positive charge of lysine residues and inhibits binding with the negatively charged DNA, thereby promoting chromatin relaxation and transcriptional activation [5]. Other new proposed mechanisms to rationalize the activity of these drugs are DNA damage and delay in DNA-repair associated with cancer cells apoptosis $[6,7]$. SAHA at doses that inhibited growth of human prostate cancer xenografts caused no detectable toxicity in mice [8], so there is interest to develop SAHA analogues as new and improved anticancer agents [9]. Analysis of the SAHA structure is used to define the pharmacophore model, comprising three elements: a) a $\mathrm{Zn}$ (II) coordinating (metal binding) group $(\mathrm{MBG})$; b) a linker region (LM), and c) a terminal aromatic (capping) group (CG) [10, 11, 12], (Fig. 1).

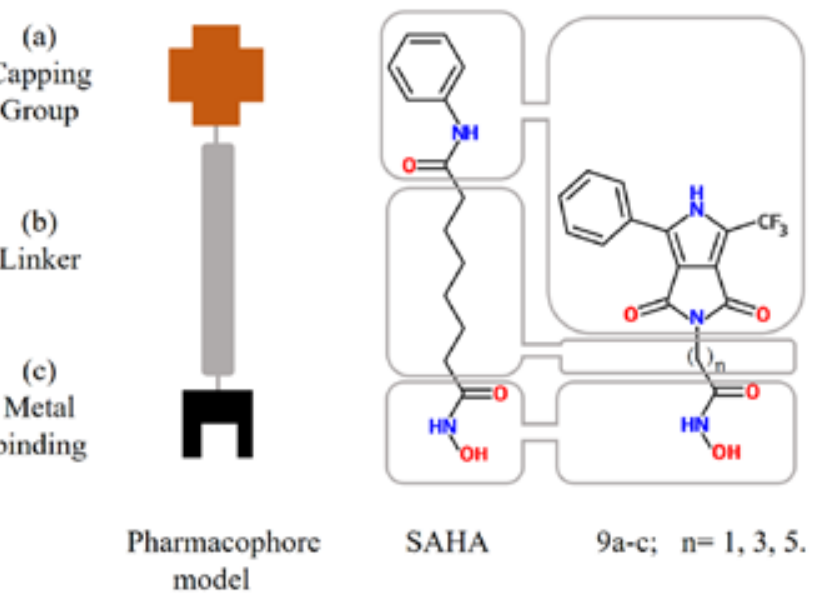

Fig. 1 Sections of the pharmacophore model in SAHA (center) and synthesized molecules in this work (right) 9a-c

Besides, our aim was to introduce a heterocyclic aromatic molecule rich in $\pi$-electron density and a trifluoromethyl group. For the former, we use the ubiquitous pyrrole system, because it can be found in drugs, such as atorvastatin, isamoltane, elopiprazole [13, 14], and molecules with biological relevance, as chlorophyll and the heme group $[15,16]$. On the other hand, the presence of the trifluoromethyl group, a bulky and highly electron-withdrawing group, which increases their chemical stability, due to the strong bonds it tends to form between C-F, can induce increased resistance to metabolic decomposition. Additionally, fluorine participates in hydrogen-bonding interactions with $\mathrm{H}-\mathrm{C}$ only as acceptor but with a much lower energy that an O-H hydrogen bond [17]. In this regard, molecules of pyrrole [18] and $-\mathrm{CF}_{3}$ [19] moieties functionalized with hydroxamic acid have been reported (Fig. 2), which exhibits interesting selectivity as inhibitors of class IIa HDACs and HDAC1 respectively. However, to the best of our knowledge there is not yet anything reported about structures where these groups are present.
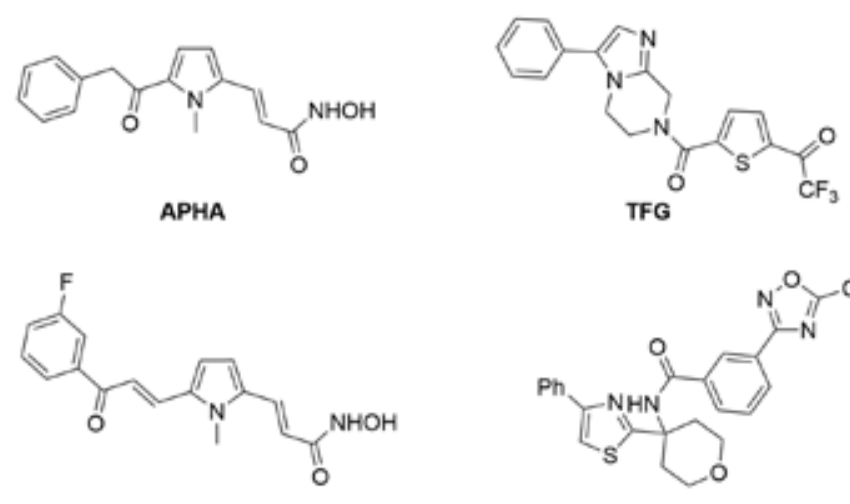

MC 1568-reassigned

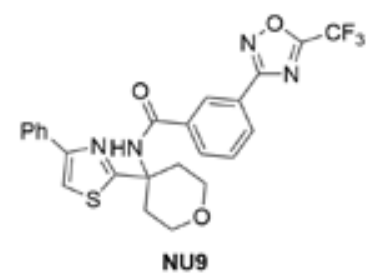

Fig. 2 Inhibitors of histone deacetylases (HDACs) with pyrrole and $-\mathrm{CF}_{3}$ moieties

Computational techniques are applied in order to justify the HDAC inhibitors activity, using extensive databases [20] and experimental crystallographic structures to corroborate the action mechanism. If such information is not available, molecular docking results a good alternative to propose a binding mode. Molecular docking is a computational methodology that is useful to understand the molecular mechanisms of substances with biological activity. In addition, docking, evaluates the most probable ways in which a macromolecule may interact with a small molecule (ligand). In the process of evaluation, many poses are tested using a set of successive stochastic and evolutive algorithms. The score of each pose is given by the quantification of the energy of intermolecular interactions [21]. Docking is useful as a tool to predict the binding mode of a ligand to a structurally-known protein, even when the ligand is not co-crystalized within the protein [22]

Our main goal is to propose new molecules that are good candidates for drugs, which show improved pharmacological activity than the reference drug SAHA. To reach our goal, we analyze the improvement of activity by modifying the LM and CG moieties of the pharmacophore model (Fig. $1)$, i.e. we modified both the linker length and the capping group (Fig. 1). In this direction, novel analogues of SAHA were synthesized with a convenient protocol beginning with the availability of the starting materials 3 and 6a-c (Scheme 1), which can be both prepared from simple synthetic meth- 
odologies. The newly synthesized analogues are: 2-(1,3-dioxo)-4-phenyl-6-(trifluoromethyl)-3,5-dihydropyrrolo[3,4-c] pyrrol-2(1H)-yl- $N$-hydroxy acetamide (9a); 4-(1,3-dioxo)-4-phenyl-6-(trifluoromethyl)-3,5-dihydropyrrolo[3,4-c] pyrrol-2(1H)-yl- $N$-hydroxy butanamide $(9 \mathrm{~b})$; and 6-(1,3-dioxo)-4-phenyl-6-(trifluoromethyl)-3,5-dihydropyrrolo[3,4-c] pyrrol-2(1H)-yl- $N$-hydroxy hexanamide (9c) (Scheme 1). To appraise the new molecules, we proceeded two-fold: a) theoretical-computational characterization using molecular docking and quantum chemical descriptors calculations and b) biological assays. Regarding the analogues of SAHA, 9a-c and their interactions with the biological target, we employed a docking methodology to assess the binding modes and the energetics involved in such couplings. Such docking analysis were performed with SAHA and the new pyrrolo $[3,4-c]$ pyrrole hydroxamic acids using 5 different HDACs isoforms: HDAC2, HDAC4, HDAC6, HDAC7 and HDAC8. Furthermore, conceptual density functional theory (DFT) [23-27] reactivity descriptors were computed at a high level of theory, to improve rationalization of the docking results. Regarding the biological assays, the cytotoxic activity was evaluated for all compounds; the new analogue $9 \mathbf{c}$ is found to have increased antiproliferative effects than SAHA in MDA-MB-231 line cells as expected from the docking calculations. The potential mechanism of action of this analogue was studied in parallel with SAHA. We employed the MCF7 cell line, an estrogenic receptor positive control cell line, and the MDA-MB-231 line, a triple negative breast cell line with mesenchymal, invasive and luminal morphology. Accumulation of acetylated histone $\mathrm{H} 3$ was measured as evidence of inhibition of histone deacetylases by SAHA and three analogues. Different types of DNA damage by comet assay at the level of individual cells were analyzed.

\subsection{Methodology}

\subsection{Chemistry}

Progress of reactions was monitored with analytical TLC (aluminum sheets, silica gel 60F/UV254) in 9:1 Hex/AcOEt system. Visualization was carried out with UV light and Iodine. All products were purified by column chromatography using silica gel (MN Kieselgel 60, 230-400 mesh) and mixtures of ethyl acetate and hexane as eluents. For reactions promoted by microwaves (MW), were performed on the equipment Discover ${ }^{\circledR}$ SP equipment using the reflux system. Melting points were determined on a digital Electrothermal 90100 melting point apparatus. ${ }^{1} \mathrm{H}$ and ${ }^{13} \mathrm{C}$ NMR spectra were recorded with a Bruker Ultrashield [500 MHz] spectrometer in $\mathrm{CDCl}_{3}$ or DMSO. High-resolution mass spectra (HRMS) were determined with electrospray ionization on a Bruker micrOTOF-Q II mass spectrometer.

Procedure for the synthesis of 4-phenyl-2-(trifluoromethyl) oxazol-5(2H)-one (3): A mixture of 2-phenylglicine $(13.91 \mathrm{mmol})$ and trifluoracetic anhydride $(20.88 \mathrm{mmol})$ were stirred at room temperature during $2.5 \mathrm{~h}$. Crude was neutralized with saturated solution of $\mathrm{NaHCO}_{3}(10 \mathrm{~mL})$. Organic phase was washed with toluene $(10 \mathrm{~mL})$, then, it was dried using vacuum and product precipitates crystals. [20]

General procedure for the synthesis of maleimides 6ac: A mixture of bromomaleic anhydride $5(3.49 \mathrm{mmol})$ and the corresponding amine hydrochloride $4 \mathbf{a}-\mathbf{c}(5.23 \mathrm{mmol})$ were dissolved in $\mathrm{AcOH}(5 \mathrm{~mL})$. The mixture was refluxed using MW for $3 \mathrm{~h}$. Solvent was removed adding $5 \mathrm{~mL}$ of toluene to the mixture and using vacuum, and repeating these 3 times. The crude was purified by column chromatography, dried under vacuum, quantified and characterized.

General procedure for the synthesis of pyrroles 7a-c: A mixture of the corresponding maleimide $\mathbf{6 a - c}(1.64 \mathrm{mmol})$ and 4-phenyl-2-(trifluoromethyl) oxazol-5(2H)-one (3.28 $\mathrm{mmol}$ ) was dissolved in toluene. The mixture was stirred at room temperature and DBU $(6.56 \mathrm{mmol})$ were added drop by drop, and was stirred for $3 \mathrm{~h}$. After this time, $\mathrm{HCl} 8 \mathrm{M}(0.1$ $\mathrm{mL}$ ) was added, the extraction of the organic phase and purification by column chromatography were carried out

General procedure for the synthesis of carboxylic acids 8a-c: A mixture of the corresponding pyrrole $7 \mathbf{a}-\mathbf{c}(0.25 \mathrm{mmol})$ and $\mathrm{HCl} 1 \mathrm{M}(2.53 \mathrm{mmol})$ were dissolved in dioxane $(5 \mathrm{~mL})$ and this was refluxed using MW for $5 \mathrm{~h}$. Crude was recrystallized to produce the carboxylic acid.

General procedure for the synthesis of pyrrolo[3,4-c] pyrrole hydroxamic acid derivatives 9a-c: These reactions were carried out under nitrogen and THF dry. A mixture of the corresponding carboxylic acid $\mathbf{8 a - c}(0.48 \mathrm{mmol})$ and carbonyl diimidazole $(0.53 \mathrm{mmol})$ were dissolved in THF ( 7.5 $\mathrm{mL}$ ). The reaction was stirred at room temperature for $1 \mathrm{~h}$. After, the hydroxylamine hydrochloride $(0.72 \mathrm{mmol})$ was added and stirred for $12 \mathrm{~h}$ at room temperature. For compounds 9a-c the purification was performed by recrystallization process.

\subsection{Computational Studies}

\subsubsection{Molecular Docking.}

The ligands 9a, 9b, 9c and SAHA (structures in Fig. 1) were initially modeled using the semiempirical AM1 method available in the Spartan'08 package [29]. Molecular docking analysis was performed using the Molegro Virtual Docker software (MVD) [30]. The aim was to calculate and compare the interaction of SAHA and the other three new pyrrolo[3,4-c]pyrrole hydroxamic acids in the binding site of the HDACs. The ligand structures were employed in their deprotonated forms only in the molecular docking studies. X-ray crystallographic structures were obtained from the Research Collaboratory for Structural Bioinformatics, (RSCB) protein data bank (PDB): HDAC2 (PDB: 4LXZ) [31] and HDAC8 (PDB: 1T69) [32] were found co-crystallized with SAHA, while HDAC4 (PDB: 2VQM) [33] and HDAC7 (PDB: 3C10) [34] were found complexed to different SAHA derivatives of the hydroxamic acid, 
and HDAC6 (PDB: 3PHD) [35] without ligands. Other human HDACs isoform-structures are still not available.

The HDACs isoforms were prepared for the molecular docking studies at $\mathrm{pH}=7$, all the water molecules were removed. During all docking minimization processes, the protein structures were kept fixed, only allowing all the torsional bonds of ligands to relax during the interaction. After blind docking, where all cavities of the protein were taken as potential binding sites, we observed how the most promising poses occur in the active site. Although the binding cavity for HDACs (and exit channel for product release) is wellknown, we performed this "blind" docking procedure to make sure that our docking methodology correctly reproduced the known binding cavity. We explored the effect of keeping the SAHA MBG and changing the LM longitude by varying the number of carbon atoms, these were $\mathrm{n}=1,3$ and 5 . In addition, we evaluated a new capping group pyrrole pyrrolidinone with trifluoromethyl and benzene substitution at positions 4 and 6 on pyrrole, respectively.

\subsubsection{DFT electronic properties}

Thereafter, electronic structure properties for the 9a, 9b, 9c and SAHA free ligands (Fig. 1) were calculated reoptimizing their geometries at the DFT level of theory, using the PBE functional and the basis set $6-311++\mathrm{G}(\mathrm{d}, \mathrm{p})$, with the Gaussian09 software [36]. True minima were obtained for all stationary points as confirmed by the harmonic analysis. Chemical descriptors were computed as $\chi=1 / 2(I+A), \eta=I-A$ and $\omega=\chi^{2} / 2 \eta$, where I and $\mathrm{A}$ are computed as the vertical ionization potential and electron affinity respectively of the species in question. They were obtained as the difference between the total energy of the cationic species (unrelaxed) and the optimized neutral molecule while $\mathrm{A}$ as the difference between the total energy of the optimized neutral molecule and its (unrelaxed) anion [37]. $\chi$ is the electronegativity, $\eta$ the absolute hardness and $\omega$ the electrophilicity.

\section{Results and Discussion}

\subsection{Chemistry}

The synthesis of the pyrrole cap derivatives 9a-c (Scheme 1) was accomplished by use of three related building blocks, namely the pyrrolo $[3,4-c]$ pyrrole hydroxamic acid derivatives 7a-c which were synthesized according to the already reported procedure [38]. The pyrrolo[3,4-c]pyrrole core was prepared by typical cycloaddition reaction between $\mathbf{3}$ and $\mathbf{6 a - c}$ in good yield. Saponification of the methyl ester followed by a standard peptide coupling reaction between the resulting acid and the hydroxylamine using CDI (carbonyldiimidazole) provided the corresponding hydroxamic acid 9a-c. The aim of the design is to analyze the effect of the $-\mathrm{CF}_{3}$ group [39], which is described as having a significant effect on biological activity. On the other hand, the core pyrrole is one of the most important heterocyclic compounds used as building blocks in the scaffold of numerous synthetic pharmaceutical agents and natural products. Details on the synthesis, isolation and characterization of compounds 9a-c can be found in the Experimental Section.

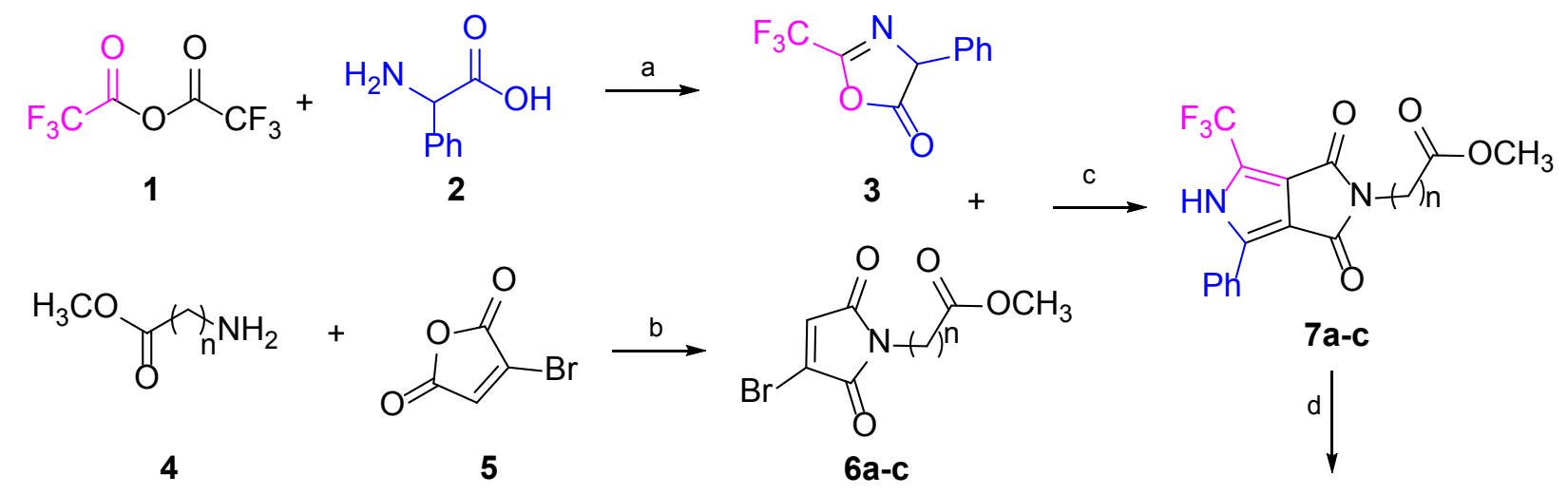

$n=$ a) 1, b) 3, c) 5
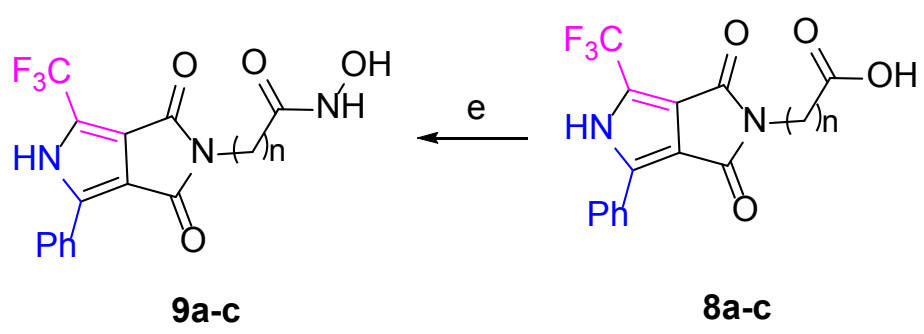

Scheme 1. Synthesis of compounds 9a-c. Reagents and conditions: (a) rt, 2.5 h, 95\%. (b) AcOH, M.W., $115{ }^{\circ} \mathrm{C}, 3$ h, 53-65\%. (c) DBU, toluene, rt, 3 h, 51-63\%. (d) HCl, dioxane, MW., $95{ }^{\circ} \mathrm{C}, 5$ h, 71-92\%. (e) $\mathrm{NH}_{2} \mathrm{OH} \cdot \mathrm{HCl}, \mathrm{CDI}, \mathrm{THF}, \mathrm{rt}, 12 \mathrm{~h}, 58-75 \%$ 


\subsection{Computational}

In order to characterize the HDACs binding mode of our three new pyrrolo[3,4-c]pyrrole hydroxamic acids, we found the optimal conditions for a refined docking process with a $0.2 \AA$ grid resolution and a sphere with a radius of $12 \AA$, centered on the active site. During the process of evaluation, many poses were tested alternating the MolDock scoring function and the Simplex Evolution search genetic algorithm with a maximum number of 1500 iterations and a 50 poses population size. Binding energies obtained from the MolDock scoring function, are calculated using equation (1), for interactions between ligands and proteins,

$$
E=\sum_{i \epsilon \text { ligand }} \sum_{j \epsilon \text { protein }}\left|E_{P L P}+332 \frac{q_{i} q_{j}}{4 r_{i j}^{2}}\right|
$$

The summation runs over all atoms, except hydrogens, in both the ligand and the protein. The $\mathrm{E}_{\mathrm{PLP}}$ term is the piecewise linear potential described on reference 30 . The second term is a Coulombic potential to describe the electrostatic interactions between charged atoms. The root-mean-square deviation (RMSD) obtained for SAHA in HDAC8 was $1.05 \AA$ (Fig. 3). The same conditions were employed for docking calculations of all the ligands.

For detailed visualization of the probable binding mode of compound $9 \mathbf{c}$, isoform HDAC8 was selected as a repre-

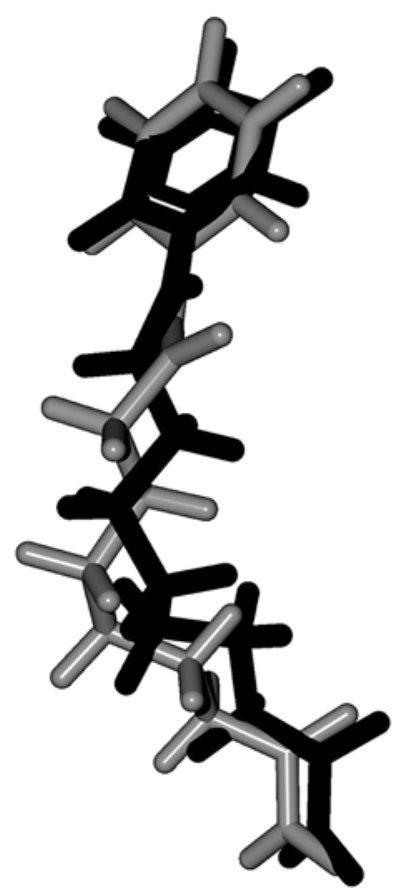

Fig. 3 The dark-colored ligand is the co-crystallized native ligand, and the other one is the highest ranked pose. The RMSD $=1.05 \AA$ sentative system model. Regarding the docking with such isoform, it was found that compound $\mathbf{9 c}$ binding is stronger than SAHA in the active site, it shows more hydrogen bond interactions. For instance, SAHA establishes a hydrogen donor bond with a nitrogen atom on the His 142 residue with a distance of $2.92 \AA$ and an angle $97.55^{\circ}$, while compound $9 \mathbf{c}$ formed two donor hydrogen bonds. The fist one of such hydrogen bonds occurs between a nitrogen atom on residue His 142 with distance of $2.81 \AA$ and angle $94.45^{\circ}$, the second one between a nitrogen atom on His 143 residue with a distance of $2.12 \AA$ and an angle of $126.22^{\circ}$. The fact that $9 \mathrm{c}$ holds two hydrogen bond interactions instead of one, compared with SAHA, evinces that $9 \mathbf{c}$ achieves a stronger interaction with HDAC8. In addition, both SAHA and $9 \mathbf{c}$, formed an acceptor hydrogen bond with hydroxyl group of residue Tyr 306, the values of distance and angle for SAHA are $1.60 \AA$ and $107.05^{\circ}$, respectively. Regarding 9c, the hydrogen bond interaction with Tyr 306 exhibits values of distance and angle of $1.78 \AA$ and $106.41^{\circ}$, respectively. Therefore, for the case of the Tyr 306 hydrogen bond interactions with both ligands are similar. Moreover, an additional acceptor hydrogen bond was found between a nitrogen atom of residue Lys 33 and the oxygen atom of $\mathbf{9 c}$ pyrrolidin-1,3-dione, the displayed distance was $2.64 \AA$ and an angle of $149.53^{\circ}$ (Fig. 4). Also, we found a candidate to a T-stacking interaction between $9 \mathbf{c}$ and the Phe 207 benzenes, such benzene moieties are separated from each other by $5.03 \AA$ measured from the ring centers (Fig. 5).

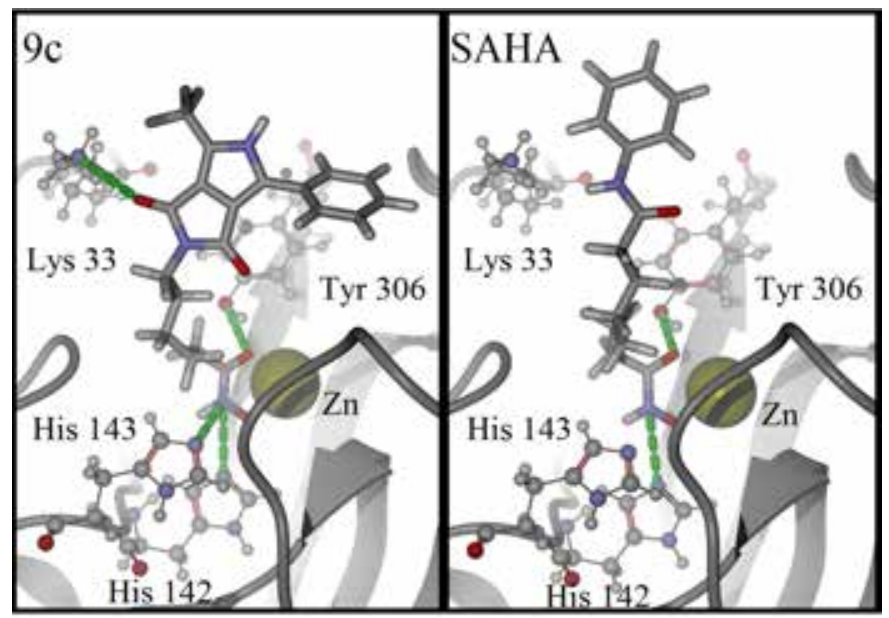

Fig. 4 Binding mode of compound 9c (left) and SAHA (right) in HDAC 8 active site. Hydrogen bonds are represented by green dotted lines. Ligands are represented as stick models, amino acids and the zinc cofactor are represented with a sphere model, all colored by atom type. Oxygen atoms are colored in red, nitrogen atoms in blue, carbon atoms on dark gray, hydrogen atoms on gray and the zinc atom in yellow. The backbone is shown as a ribbon 


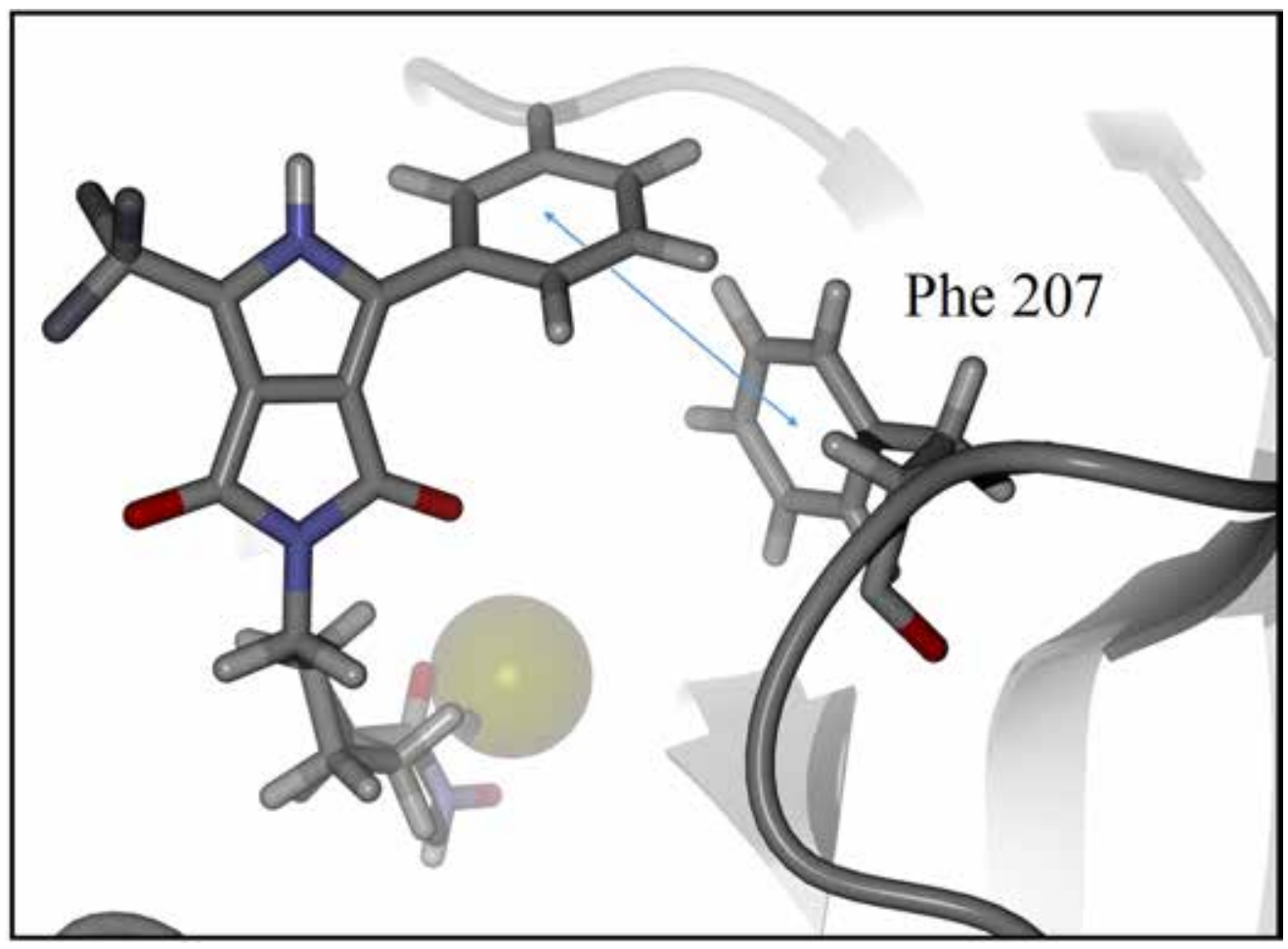

Fig. 5 Candidate to T-stacking interaction between $\mathbf{9 c}$ and phenylalanine residue in the HDAC8 active site. Ligand $\mathbf{9 c}$ and key residue are represented as a stick model, colored by atom type, zinc represented as sphere model and the backbone is shown as a ribbon. The blue arrow represents the measured distance, $5.03 \AA$

Table 1. Calculated binding energies $\left(\mathrm{kcal} \mathrm{mol}^{-1}\right)$ for all compound-HDAC isoform complexes.

\begin{tabular}{|l|l|l|l|l|l|l|}
\hline $\begin{array}{l}\text { Compound/ } \\
\text { Isoform }\end{array}$ & HDAC2 & HDAC4 & HDAC6 & HDAC7 & HDAC8 & Average \\
\hline 9a & -93.31 & -98.77 & -85.62 & -93.58 & -68.94 & $\mathbf{- 8 8 . 0 4}$ \\
\hline 9b & -77.46 & -89.52 & -103.45 & -111.42 & -95.65 & $\mathbf{- 9 5 . 5 0}$ \\
\hline 9c & -135.93 & -70.80 & -100.63 & -123.75 & -93.12 & $\mathbf{- 1 0 4 . 8 5}$ \\
\hline SAHA & -131.97 & -85.62 & -83.16 & -103.87 & -78.67 & $\mathbf{- 9 6 . 6 6}$ \\
\hline
\end{tabular}

The binding energies of all molecules with each of HDAC isoforms were calculated and reported on Table 1. To analyze the cooperative or cumulative effect that is due to the presence and action of the five isoforms, we report an average binding energy in the last column.

As it can be seen in Table 1, the highest average binding energy suggests that compound $9 \mathbf{c}$ is the most active molecule, with capacity to block the active sites of a variety of HDAC isoforms, followed by SAHA. In order to corroborate such results, biological tests were performed resulting in agreement with the theoretical predictions, where the most active molecule was found to be compound 9c. Besides, our results show that the binding modes of SAHA and $\mathbf{9 c}$ are very similar. Such binding modes for both molecules involve the hydroxamic group that appears very close to the zinc cofactor (Fig. 6). Several experimental and theoretical studies $[10,40]$ bring to light that this is the strongest interaction, our results support that this mode of interaction is fundamental to the biological activity and should be preserved to improve the binding energy, and hopefully the anticancer activity. It is known, that SAHA and the new $\mathbf{9 c}$ inhibitor are not specific (selective) to any of the HDAC isoforms. For that reason, since we lack the precise information about which HDAC isoforms are binding to SAHA and derivatives, is why we are studying the binding modes and energetics on 5 available HDAC isoforms and also have computed the average interaction energy, (Table 1 and Figure 6), which clearly indicates that one of the inhibitors, $\mathbf{9 c}$, would show improved binding over SAHA, which is confirmed by the experimental results.

The complete set of HDAC isoforms is still not available, therefore we cannot calculate the binding energy and study the total effect, and our results are therefore circumscribed to the 5 isoforms discussed in this paper. 


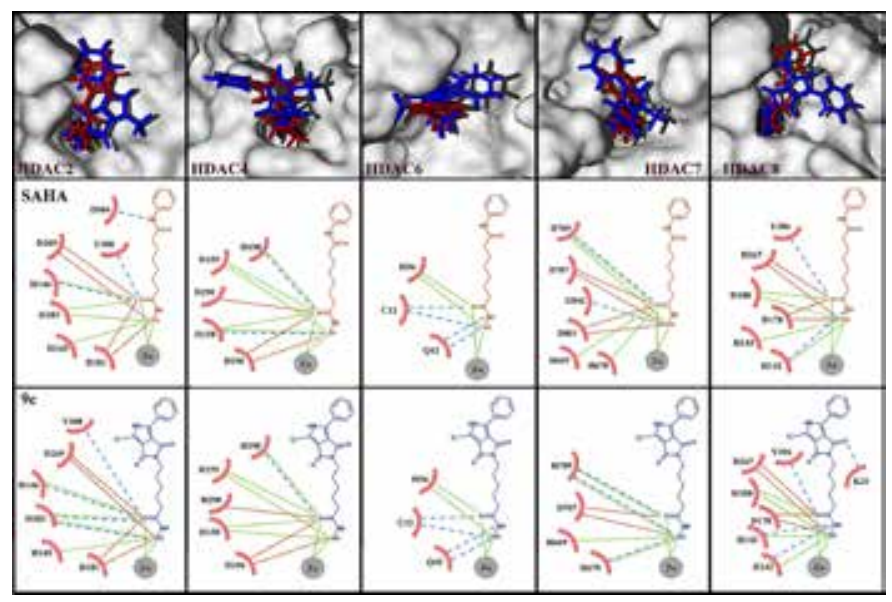

Fig. 6 Surfaces of 5 different HDACs isoforms with superposition of $9 c$ (blue) and SAHA (red) docked. The view displayed is an inset of the active site, in all cases the hydroxamic group remains at the interior of the active sites and benzene rings remain outside. Bottom: Principal hydrogen bonds and electrostatic interactions taking place in such poses. Dashed lines in blue represent hydrogen bond interactions, continuous lines in green represent attractive electrostatic interactions and dot lines in red represent repulsive electrostatic interactions

In the HDAC2 isoform, SAHA establishes an extra donor hydrogen bond with an aspartate residue in comparison with 9c. However, 9c keeps two acceptor hydrogen bonds with a His 183 residue; the total interaction is stronger for $\mathbf{9 c}$ than SAHA. Only for the HDAC4 isoform, SAHA is better docked than $9 \mathrm{c}$ by an acceptor hydrogen bond with His 158 . Regarding the HDAC6 isoform, hydrogen bonds and electrostatic interactions are similar for both ligands. For HDAC7 isoform SAHA displays repulsive electrostatic interactions with two aspartate residues, 707 and 801, while 9c only interacts with Asp 707. In the HDAC8 isoform, the ligand $9 \mathbf{c}$ holds an extra acceptor hydrogen bond with Lys 33 and another extra donor hydrogen bond with His 143 in comparison with SAHA binding mode.

To get information about how $\mathbf{9 a}$ and $\mathbf{9 b}$ compounds are biologically inactive, we calculated a hydrophobicity surface around the active site of HDAC8. We can observe how the middle section of the active site has a non-polar residue, Phe 152, such residue holds a non-effective interaction with the polar pyrrolidin-1,3-dione oxygen atom of $9 a$, the same non-effective interaction is displayed for $\mathbf{9 b}$. A different case is observed for $\mathbf{9 c}$, the size of the aliphatic chain situates the pyrrolidin-1,3-dione oxygen atom outside the tunnel of the active site and creates an effective hydrophilic interaction with the polar residue Lys 33 (Fig. 7). In addition, the phenylalanine residue is in the center of the active site in all the other HDAC isoforms.

To characterize the effect of changing the functional groups of the capping group in the improvement of the binding energy, DFT chemical descriptors were calculated at the PBE/6-311++G(d,p) level of theory and are reported in Table 2. It can be seen, from the analysis of the electronic affinity values, that the greatest correspond to the $9 \mathbf{a}$ and $9 \mathbf{b}$ compounds,

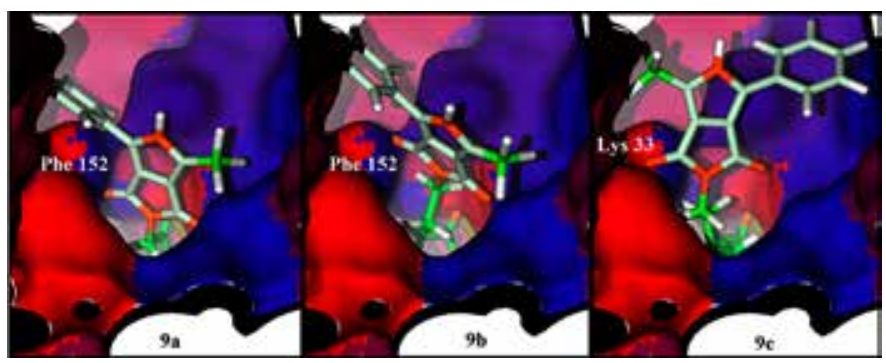

Fig. 7 Hydrophobicity surface of the HDAC8 active site with 9a (left), 9b (center) and 9c (right) docked. Oxygen and nitrogen atoms colored in orange, polar amino acids in red, non-polar amino acids in blue and violet, key residues Phe 152 in blue and Lys 33 in red.

being therefore the ones more eager to accept an additional electron. This behavior is at variance with $\mathbf{9 c}$, which is the closest to the SAHA value, and found in the docking studies to be the best performer. SAHA has the smaller value of A of the four compounds and therefore it seems that both $9 \mathbf{c}$ and SAHA are the least capable to accept electrons during the binding process. For all other chemical DFT descriptors in Table 2, except for the case of hardness, we find that the closest values to SAHA are those of compound $9 \mathbf{c}$. The greatest ionization potentials are those of the $9 \mathbf{a}$ and $9 \mathbf{b}$ compounds and the smaller $9 \mathbf{c}$ value is quite close to the SAHA value. This indicates a better capability to donate electrons of the two latter species; this will correspond with the fact that the binding mode of these compounds to the $\mathrm{Zn}$ cofactor in the HDAC active site is enhanced by the ability of $9 \mathbf{c}$ and SAHA to more easily donate electrons as compared to $9 \mathbf{a}$ and $9 \mathbf{b}$. In Fig. 8 we show the trends of the main conceptual DFT global chemical descriptors for our new compounds and are compared to SAHA.

SAHA and $9 c$ display the closest values for most descriptors. With this regard, our computational studies suggest that the best performance of the new hydroxamic acids in the HDAC active site turns out to be the one more similar to SAHA in its DFT chemical descriptor values. From values in Table 2 and Fig. 8, it seems that the interaction between the HDAC active site and the hydroxamic acid molecule is more efficient when the ligand is a better electron donor, consequently it seems that the HDAC active site behaves as a good electron acceptor.

Such results evince that the electronic characteristics of the $9 c$ analogue contribute to make it the molecule with the best binding energy, and are useful to understand the physicochemical properties behind the biological activity. 


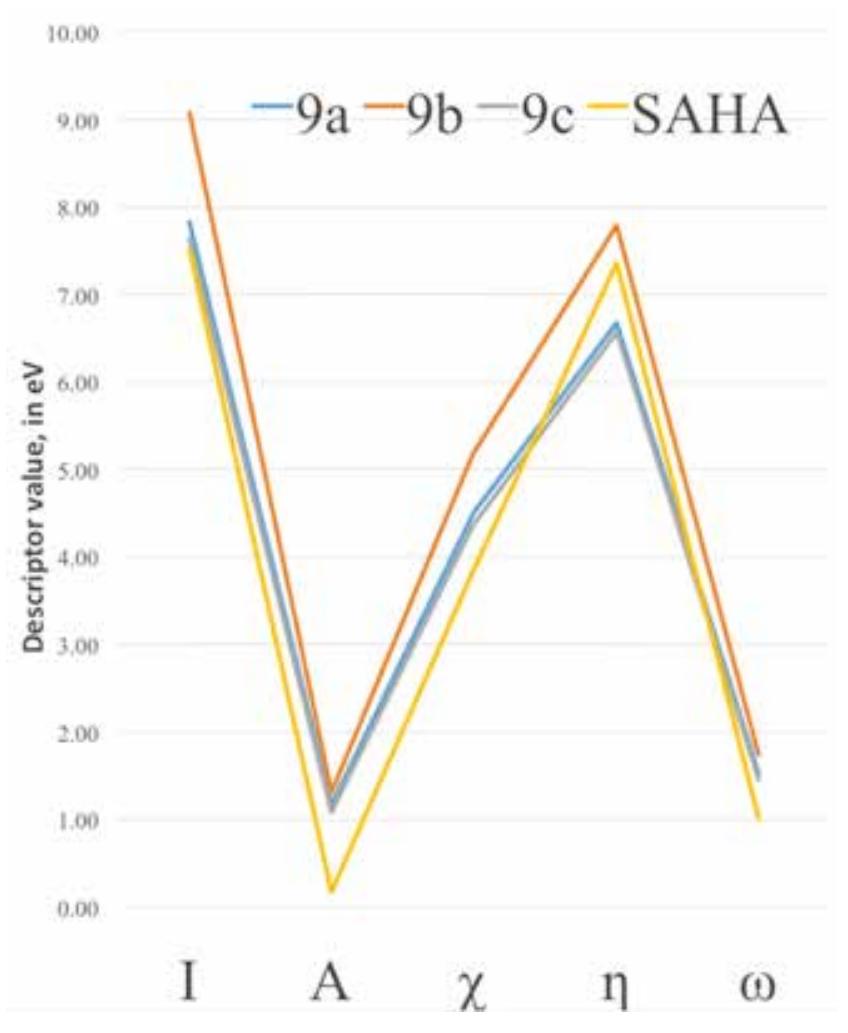

Fig. 8 DFT Electronic global descriptors: Ionization potential (I), Electron Affinity (A), Electronegativity $(\chi)$, absolute hardness $(\eta)$ and electrophilicity $(\omega)$, calculated for SAHA and the new SAHA analogues

Table 2. DFT electronic properties for the 4 free hydroxamic acids. Theory level for optimized molecules is PBE/6-311++G(d,p)

\begin{tabular}{lccccc}
\hline Ligands & $\mathbf{I} / \mathbf{e V}$ & $\mathbf{A} / \mathbf{e V}$ & $\chi / \mathbf{e V}$ & $\boldsymbol{\eta} / \mathbf{e V}$ & $\boldsymbol{\omega} / \mathbf{e V}$ \\
9a & 7.82 & 1.16 & 4.49 & 6.66 & 1.51 \\
9b & 9.06 & 1.29 & 5.18 & 7.77 & 1.72 \\
9c & 7.63 & 1.07 & 4.35 & 6.56 & 1.44 \\
SAHA & 7.51 & 0.16 & 3.83 & 7.35 & 1.00 \\
\hline
\end{tabular}

\subsection{Biological studies}

To further evaluate the efficiency of our new $9 c$ inhibitor as predicted from the computational and docking analyses, we performed a number of biological tests: cytotoxic assay, histone $\mathrm{H} 3$ acetylation and DNA damage studies.

\subsubsection{Cytoxicity assay of SAHA and analogues in two cells line}

The anti-proliferative effect of SAHA was evaluated by the 3-(4,5-dimethylthiazol-2-yl)-2,5-diphenyltetrazolium bromide, (MTT), assay on MCF7 and MDA-MB-231 cell lines that were treated with different concentrations of SAHA $(1,2.5,5$ and 10 $\mathrm{mmol} / \mathrm{L}$ ) during 24, 48 and $72 \mathrm{~h}$. In Table 3 it is shown that the $\mathrm{IC}_{50}$ value of $9 \mathrm{c}$ after $48 \mathrm{~h}$ is lower than the value displayed by SAHA. For this reason, compound $\mathbf{9 c}$ appears to be more potent than SAHA in a MDA-MB-231 cell line.
In Fig. 9 it is shown that SAHA and the 9c analogue reduce the percent of viable cells at $\mathrm{IC}_{50}$ concentration. The $9 \mathrm{c}$ analogue improves over SAHA particularly in the MDA-MB-231 cell line.

Table 3. $\mathrm{IC}_{50}$ of SAHA and $9 \mathrm{c}$ analogue $(\mu \mathbf{M})$ in both cells lines at $48 \mathrm{~h}$, each value represents the mean $\pm \mathrm{SD}$ of three independent experiments.

\begin{tabular}{llc}
\hline & IC $_{\mathbf{5 0}}$ & IC $_{\mathbf{5 0}}$ \\
& SAHA $(\mu \mathrm{M})$ & $\mathbf{9 c}(\mu \mathrm{M})$ \\
MCF7 & $2.1 \pm 0.3$ & $7.6 \pm 0.7$ \\
MDA-MB-231 & $3.1 \pm 0.3$ & $1.6 \pm 0.2$ \\
\hline
\end{tabular}

\subsubsection{Histone (H3) Acetylation}

Docking studies were performed on HDAC enzymes. The biological function of these enzymes is the deacetylation of histones. We analyze the level of histone acetylation in two cell lines. The acetylated histone $\mathrm{H} 3$ protein levels were increased in MCF7 by SAHA, 9b and 9c; in MDA-MB-231 cell lines by SAHA and 9c compound as compared to non-treated controls. Since histone deacetylation inhibition is a proposed mechanism of SAHA and derivatives, increase in histone acetylation $\mathrm{H} 3$ is consistent with our docking studies. HDACi binding was used to prove compounds with the HDAC pocket that correlated with the level of acetylated histone (Fig. 10). In addition, compounds displaying small level of binding energy did not show an increase in histone $\mathrm{H} 3$ acetylation, such as $\mathbf{9 a}$ and $\mathbf{9 b}$, in both cell lines.

\subsubsection{DNA damage}

The 9c pyrrole derivative induced the highest level of DNA damage and oxidative DNA damage in the MDA-MB-231 cell line (Fig. 11a). In contrast, SAHA induced the highest DNA and Oxidative DNA damage in the MCF-7 cell line, as can be seen in Fig. 11b.

We found that both compounds induced oxidative DNA damage as well as single and double breaks in DNA. Another report suggests that SAHA suppresses DNA DSB repair proteins such as RAD50 and MER11 in cancer cells [41]. This may be an explanation for DNA damage in cells treated with SAHA. Another factor that increases the susceptibility to DNA damage in cells treated with deacetylase inhibitor compounds; is the accumulation of histone acetylation which itself could alter chromatin structure. We propose that DNA damage itself is a relevant mechanism to induce cytotoxicity.

\section{Conclusions}

Our studies have expanded the in-silico design, synthesis and biological evaluation of SAHA analogues. The nuclei pyrrolo[3,4-c]pyrrole hydroxamic acid (9a-c) have been obtained by mild reaction conditions, these compounds were characterized by NMR spectroscopy and HRMS. Our results show that the new SAHA analogue 9c has better anticancer activity 
MDA-MB-231

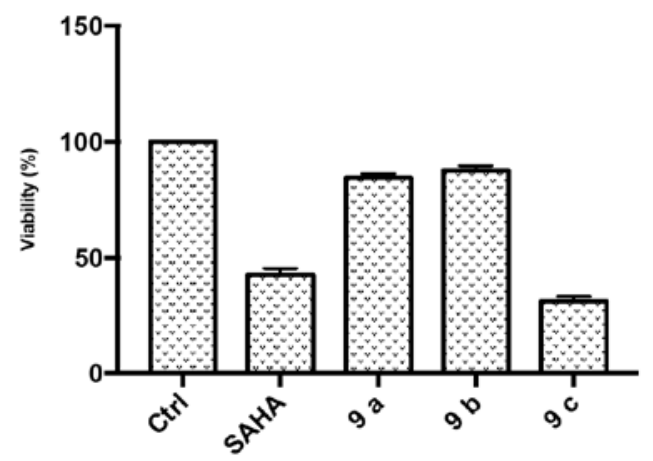

MCF7

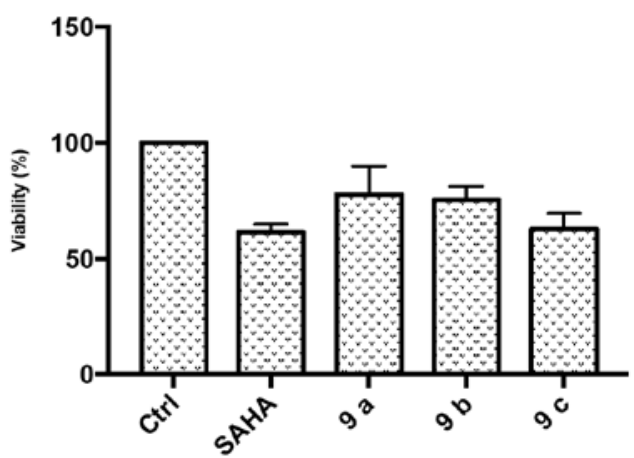

Fig. 9 Anti-proliferative activity of SAHA and analogues. The mean of three independent experiments \pm SD at $\mathrm{IC}_{50}$ dose for $\mathrm{SAHA}$ is shown in each cell line at $48 \mathrm{~h}$
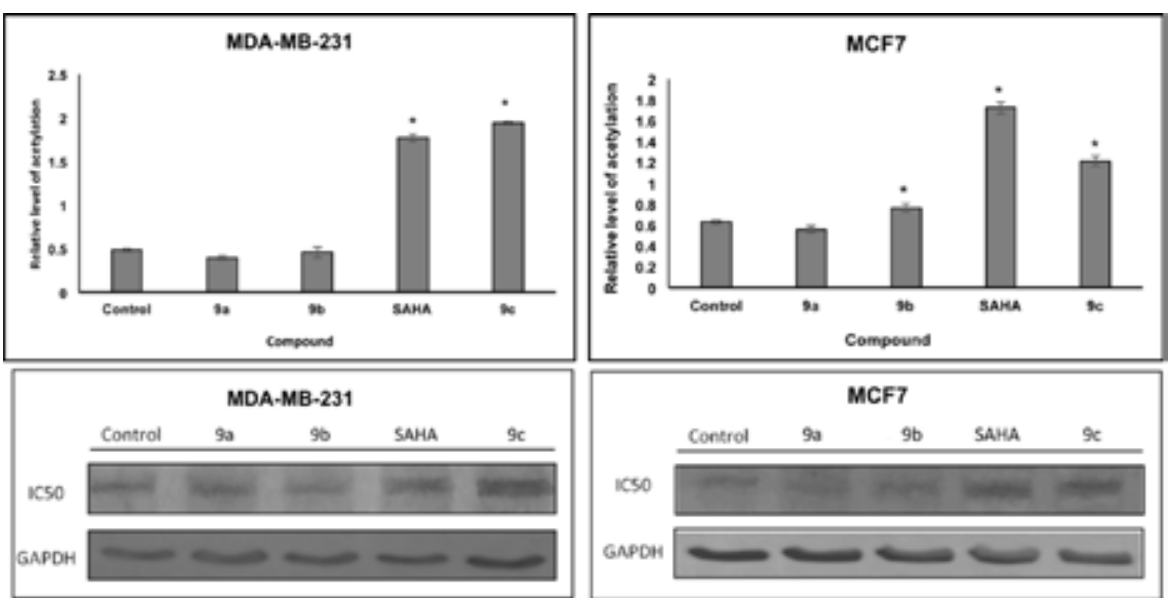

Fig. 10 Effects of SAHA and analogues $(\mathbf{9 a}, 9 \mathbf{b}$ and $\mathbf{9 c})$ on histone acetylation of two cell lines. Cells were treated with $\mathrm{IC}_{50}$ concentrations of SAHA for $48 \mathrm{~h}$. Equal amounts of proteins were loaded. The graphs represent the mean \pm SD of three independent experiments. Statistical difference for control $\mathrm{p}<0.05^{*}$

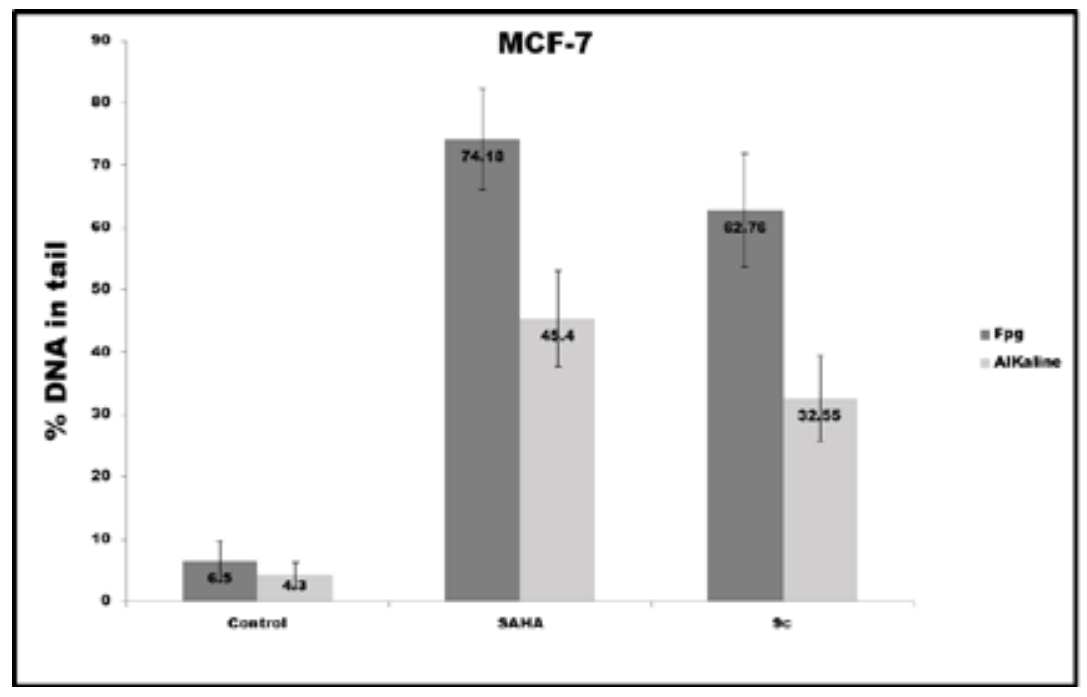

Fig. 11 DNA damage (alkaline) and oxidative DNA damage (Fpg) expressed in \% DNA in tail induced in different conditions in both cell lines 
than SAHA in the MDA-MB-231 line cells, produces more H3 acetylation and induces more oxidative DNA damage in the MDA-MB-231 cell line. Such findings agree very well with our computational molecular docking and DFT study, which exhibited that the only molecule in this comparative study with capacity to improve SAHA activity like an HDAC inhibitor is 9c, in excellent agreement with the cytotoxic tests.

\section{Experimental}

\subsection{Chemistry}

4-Phenyl-2-(trifluoromethyl) oxazol-5(2H)-one (3).

Yield 95\%, yellow solid, ${ }^{1} \mathrm{H}$ NMR (500 MHz, $\left.\mathrm{CDCl}_{3}\right) \delta: 8.43$ $(\mathrm{d}, J=7.5 \mathrm{~Hz}, 2 \mathrm{H}), 7.65$ (t, $J=7 \mathrm{~Hz}, 1 \mathrm{H}), 7.54(\mathrm{t}, J=7 \mathrm{~Hz}$, 2H), $6.26(\mathrm{~s}, 1 \mathrm{H}) .{ }^{13} \mathrm{C} \mathrm{NMR}\left(125 \mathrm{MHz}, \mathrm{CDCl}_{3}\right) \delta 162.7,160.6$, $134.0,129.1,129.1,127.3,123.7-117.0(\mathrm{q}, J=280), 92.8-92.0$ $(\mathrm{q}, J=35.12)$.

Methyl 2-(3-bromo-2,5-dioxo-2,5-dihydro-1 $H$-pyrrol-1-yl) acetate (6a).

Yield 53\%, brown liquid, ${ }^{1} \mathrm{H}$ NMR $\left(500 \mathrm{MHz}, \mathrm{CDCl}_{3}\right)$ : $\delta$ $6.73(\mathrm{~s}, 1 \mathrm{H}), 4.31$ (s, 2H), 3.77 (s, 3H). ${ }^{13} \mathrm{C}$ NMR (125 MHz, $\left.\mathrm{CDCl}_{3}\right): \delta 167.5,167.2,164.1,141.3,127.2,52.7,39.1-39.2$. HRMS $\left(\mathrm{EI}^{+}\right)$: calcd for $\mathrm{C}_{7} \mathrm{H}_{6} \mathrm{BrNO}_{4}^{+}[\mathrm{M}+\mathrm{H}]^{+}, 246.9480$; found, 246.9483.

Ethyl 4-(3-bromo-2,5-dioxo-2,5-dihydro-1 $H$-pyrrol-1-yl) butanoate (6b).

Yield 63\%, brown liquid, ${ }^{1} \mathrm{H}$ NMR $\left(500 \mathrm{MHz}, \mathrm{CDCl}_{3}\right) \delta: 6.64$ (s, 1H), 4.13 (c, $J=7.1 \mathrm{~Hz}, 2 \mathrm{H}), 3.64-3.61(\mathrm{~m}, J=3.5 \mathrm{~Hz}, 2 \mathrm{H})$, 2.32 (t, $J=7.3 \mathrm{~Hz}, 2 \mathrm{H}), 1.91-1.96$ (q, $J=7 \mathrm{~Hz}, 2 \mathrm{H}), 1.26$ (t, $J$ $=7.1 \mathrm{~Hz}, 3 \mathrm{H}) .{ }^{13} \mathrm{C} \mathrm{NMR}\left(125 \mathrm{MHz}, \mathrm{CDCl}_{3}\right): \delta 172.4,168.4$, 165.2, 140.9, 126.7, 60.6, 37.9, 31.4, 23.6, 14.1. HRMS $\left(\mathrm{EI}^{+}\right)$: calcd for $\mathrm{C}_{9} \mathrm{H}_{10} \mathrm{BrNO}_{4}^{+}[\mathrm{M}+\mathrm{H}]^{+}, 274.9793$; found, 274.9801 .

Methyl 6-(3-bromo-2,5-dioxo-2,5-dihydro-1 $H$-pyrrol-1-yl) hexanoate (6c).

Yield 65\%; brown liquid, ${ }^{1} \mathrm{H}$ NMR $\left(500 \mathrm{MHz}, \mathrm{CDCl}_{3}\right) \delta 6.64$ (s, 1H), 4.13 (c, $J=7.1 \mathrm{~Hz}, 2 \mathrm{H}), 3.64-3.61(\mathrm{~m}, J=3.5 \mathrm{~Hz}, 2 \mathrm{H})$, 2.32 (t, $J=7.3 \mathrm{~Hz}, 2 \mathrm{H}), 1.91-1.96$ (q, $J=7 \mathrm{~Hz}, 2 \mathrm{H}), 1.26$ (t, $J$ $=7.1 \mathrm{~Hz}, 3 \mathrm{H}) \cdot{ }^{13} \mathrm{C} \mathrm{NMR}\left(125 \mathrm{MHz}, \mathrm{CDCl}_{3}\right): \delta 172.4,168.4$, 165.2, 140.9, 126.7, 60.6, 37.9, 31.4, 23.6, 14.1. HRMS (EI $\left.{ }^{+}\right)$: calcd for $\mathrm{C}_{11} \mathrm{H}_{14} \mathrm{BrNO}_{4}^{+}[\mathrm{M}+\mathrm{H}]^{+}, 303.0106$; found, 303.0111 .

Methyl 2-(1,3-dioxo)-4-phenyl-6-(trifluoromethyl)-3,5-dihydropyrrolo[3,4-c]pyrrol-2(1H)-yl-acetate $(7 \mathbf{a})$.

Yield 51\%; white powder, mp 205-206 ${ }^{\circ} \mathrm{C},{ }^{1} \mathrm{H}$ NMR $(500 \mathrm{MHz}$, $\left.\mathrm{CDCl}_{3}\right) \delta: 10.12(\mathrm{~s}, 1 \mathrm{H}), 7.96(\mathrm{~d}, J=6.7 \mathrm{~Hz}, 2 \mathrm{H}), 7.48-7.37(\mathrm{~m}$, $3 \mathrm{H}), 4.38$ (s, 2H), 3.80 (s, 3H). ${ }^{13} \mathrm{C} \mathrm{NMR}\left(125 \mathrm{MHz}, \mathrm{CDCl}_{3}\right) \delta$ : $168.5,162.7,160.7,133.8,130.4,129.2,127.2,127.2,126.3$, $122.2-115.8$ (q, $J=267.25 \mathrm{~Hz}), 121.7,117.5-116.4(\mathrm{q}, J=43.5$ $\mathrm{Hz}), 116.5,115.8,52.7,39.1$. HRMS $\left(\mathrm{EI}^{+}\right)$: calcd for $\mathrm{C}_{16} \mathrm{H}_{11} \mathrm{~F}-$ ${ }_{3} \mathrm{~N}_{2} \mathrm{O}_{4}^{+}[\mathrm{M}+\mathrm{H}]^{+}, 352.0671$; found, 352.0675 .

Ethyl 4-(1,3-dioxo)-4-phenyl-6-(trifluoromethyl)-3,5-dihydropyrrolo[3,4-c]pyrrol-2(1H)-yl-butanoate (7b).
Yield 53\%; white powder, mp 153-154 ${ }^{\circ} \mathrm{C},{ }^{1} \mathrm{H}$ NMR $(500 \mathrm{MHz}$, $\left.\mathrm{CDCl}_{3}\right) \delta: 10.71(\mathrm{~s}, 1 \mathrm{H}), 8.07(\mathrm{~d}, J=8 \mathrm{~Hz}, 2 \mathrm{H}), 7.48-7.33(\mathrm{~m}$, $3 \mathrm{H}), 4.11$ (c, $J=7 \mathrm{~Hz}, 2 \mathrm{H}), 3.67$ (t, $J=7 \mathrm{~Hz}, 2 \mathrm{H}), 2.37$ (t, $J=7.5 \mathrm{~Hz}, 2 \mathrm{H}), 2.03-1.91(\mathrm{q}, \mathrm{J}=7 \mathrm{~Hz}, 2 \mathrm{H}), 1.23$ (t, $J=7$ $\mathrm{Hz}, 3 \mathrm{H}) .{ }^{13} \mathrm{C} \mathrm{NMR}\left(125 \mathrm{MHz}, \mathrm{CDCl}_{3}\right) \delta: 173.3,163.9,162.1$, $133.8,130.1,129.1,127.6,126.4,122.4-115.9$ (c, $J=267.25$ $\mathrm{Hz}, 1 \mathrm{C}$ ), 121.8, 117.3-116.2 (c, $J=43.5 \mathrm{~Hz}, 1 \mathrm{C}), 116.6,60.7$, $37.5,31.7,23.9$, 14. HRMS $\left(\mathrm{EI}^{+}\right)$: calcd for $\mathrm{C}_{18} \mathrm{H}_{15} \mathrm{~F}_{3} \mathrm{~N}_{2} \mathrm{O}_{4}^{+}[\mathrm{M}$ $+\mathrm{H}]^{+}, 380.0984$; found, 380.0989 .

Methyl 6-(1,3-dioxo)-4-phenyl-6-(trifluoromethyl)-3,5-dihydropyrrolo[3,4-c]pyrrol-2(1H)-yl-hexanoate $(7 \mathrm{c})$.

Yield $63 \%$, white powder, mp $148{ }^{\circ} \mathrm{C},{ }^{1} \mathrm{H}$ NMR $(500 \mathrm{MHz}$, $\left.\mathrm{CDCl}_{3}\right) \delta: 10.67(\mathrm{~s}, 1 \mathrm{H}), 8.08(\mathrm{~d}, J=7 \mathrm{~Hz}, 2 \mathrm{H}), 7.47-7.37(\mathrm{~m}$, $3 \mathrm{H}), 3.65(\mathrm{~s}, 3 \mathrm{H}), 3.60(\mathrm{t}, J=7 \mathrm{~Hz}, 2 \mathrm{H}), 2.30(\mathrm{t}, J=7.5 \mathrm{~Hz}$, 2H), 1.69-1.58 (m, 4H), 1.40-1.28 (q, J = 7.5, 2H). ${ }^{13} \mathrm{C} \mathrm{NMR}$ $\left(125 \mathrm{MHz} \mathrm{CDCl}_{3}\right) \delta: 174.5,163.9,162.1,133.6,130.2,129.1$, $127.7,122.4-116$ (c, $J=267.5), 122.1,117.2-116.2$ (c, $J=$ 43.62), 116.9, 51.6, 38.1, 33.9, 28.2, 26.3, 24.4. HRMS $\left(\mathrm{EI}^{+}\right)$: calcd for $\mathrm{C}_{20} \mathrm{H}_{19} \mathrm{~F}_{3} \mathrm{~N}_{2} \mathrm{O}_{4}{ }^{+}[\mathrm{M}+\mathrm{H}]^{+}, 408.1297$; found, 408.1301 .

2-(1,3-Dioxo)-4-phenyl-6-(trifluoromethyl)-3,5-dihydropyrrolo[3,4-c]pyrrol-2(1H)-yl-acetic acid (8a).

Yield 71\%, white powder, mp 204-206 ${ }^{\circ} \mathrm{C},{ }^{1} \mathrm{H}$ NMR $(500 \mathrm{MHz}$, $\left.\mathrm{CDCl}_{3}\right) \delta: 10.12(\mathrm{~s}, 1 \mathrm{H}), 7.96(\mathrm{~d}, J=6.7 \mathrm{~Hz}, 2 \mathrm{H}), 7.48-7.37(\mathrm{~m}$, $3 \mathrm{H}), 4.38$ (s, 2H), 3.80 (s, 3H). ${ }^{13} \mathrm{C} \mathrm{NMR}\left(125 \mathrm{MHz}, \mathrm{CDCl}_{3}\right) \delta$ : $168.5,162.7,160.7,133.8,130.4,129.2,127.2,127.2,126.3$, $122.2-115.8$ (c, $J=43.5 \mathrm{~Hz}), 121.7,117.5-116.4$ (c, $J=267.25$ $\mathrm{Hz}), 116.5,115.8,52.7,39.1$.

4-(1,3-Dioxo)-4-phenyl-6-(trifluoromethyl)-3,5-dihydropyrrolo[3,4-c]pyrrol-2(1H)-yl-butanoic acid $(8 \mathrm{~b})$.

Yield 90\%, white powder, mp 205-207 ${ }^{\circ} \mathrm{C},{ }^{1} \mathrm{H}$ NMR $(500 \mathrm{MHz}$, DMSO) $\delta: 13.48(\mathrm{~s}, 1 \mathrm{H}), 12.07(\mathrm{~s}, 1 \mathrm{H}), 8.24(\mathrm{~d}, J=8 \mathrm{~Hz}, 2 \mathrm{H})$, 7.55 (t, $J=7.5 \mathrm{~Hz}, 2 \mathrm{H}), 7.49(\mathrm{t}, J=7 \mathrm{~Hz}, 1 \mathrm{H}), 3.55$ (t, $J=6.5$ $\mathrm{Hz}, 2 \mathrm{H}), 2.27$ (t, $J=7 \mathrm{~Hz}, 2 \mathrm{H}), 1.81$ (q, $J=7 \mathrm{~Hz}, 2 \mathrm{H}) .{ }^{13} \mathrm{C}$

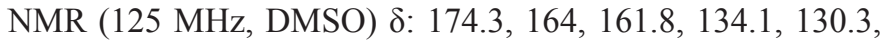
$129.4,128.4,127.1,123.1-116.7(\mathrm{c}, J=267), 122.3,117,116.6-$ 115.6(c, $J=43), 37.6,31.4,23.8$.

6-(1,3-Dioxo-4-phenyl-6-(trifluoromethyl)-3,5-dihydropyrrolo[3,4-c]pyrrol-2(1H)-yl)hexanoic acid $(8 \mathrm{c})$.

Yield $92 \%$, white powder, mp $169-170{ }^{\circ} \mathrm{C},{ }^{1} \mathrm{H}$ NMR $(500 \mathrm{MHz}$, DMSO) $\delta: 13.49(\mathrm{~s}, 1 \mathrm{H}), 11.98(\mathrm{~s}, 1 \mathrm{H}), 8.24(\mathrm{~d}, J=7.5 \mathrm{~Hz}, 2 \mathrm{H})$, 7.55 (t, $J=7.5 \mathrm{~Hz}, 2 \mathrm{H}), 7.48$ (t, $J=7 \mathrm{~Hz}, 1 \mathrm{H}), 3.49$ (t, $J=7.0$ $\mathrm{Hz}, 2 \mathrm{H}), 2.20$ (t, $J=7.5 \mathrm{~Hz}, 2 \mathrm{H}), 1.62-1.46(\mathrm{~m}, 4 \mathrm{H}), 1.33-1.23$ (q, $J=8.5,2 \mathrm{H}) .{ }^{13} \mathrm{C}$ NMR (125 MHz, DMSO) $\delta: 201.9,174.8$, $163.9,161.8,134.2,130.3,129.4,128.4,127.1,123.1-116.7(\mathrm{c}$, $J=267), 122.2,116.9,116.7-115.7(\mathrm{c}, J=42.87), 37.9,33.9$, $28.2,26.2,24.5$.

2-(1,3-Dioxo)-4-phenyl-6-(trifluoromethyl)-3,5-dihydropyrrolo[3,4-c]pyrrol-2(1H)-yl- $\mathrm{N}$-hydroxyacetamide (9a).

Yield: 58\%, white powder, mp $197-198{ }^{\circ} \mathrm{C},{ }^{1} \mathrm{H}$ NMR $(500$ $\mathrm{MHz}, \mathrm{DMSO}) \delta: 10.80(\mathrm{~s}, 1 \mathrm{H}), 10.46-9.32(\mathrm{~d}, 1 \mathrm{H}), 8.96(\mathrm{~s}$, $1 \mathrm{H}), 8.23$ (d, $J=6.5 \mathrm{~Hz}, 2 \mathrm{H}), 7.56$ (d, $J=7.2 \mathrm{~Hz}, 2 \mathrm{H}), 7.53-$ 
7.47 (m, 1H), 4.35 (s, 2H). ${ }^{13} \mathrm{C}$ NMR (125 MHz, DMSO) $\delta$ : $163.9,163.1,161,134.9,130.5,129.4,128.3,127.2,122.1$ $116.6(\mathrm{c}, J=267 \mathrm{~Hz}), 121.7,117.3-116.5(\mathrm{c}, J=43.37), 117$, 116.5, 52.8. HRMS $\left(\mathrm{EI}^{+}\right)$: calcd for $\mathrm{C}_{15} \mathrm{H}_{11} \mathrm{~F}_{3} \mathrm{~N}_{3} \mathrm{O}_{4}{ }^{+}[\mathrm{M}+\mathrm{H}]^{+}$, 354.0696; found, 354.0759 .

4-(1,3-Dioxo)-4-phenyl-6-(trifluoromethyl)-3,5-dihydropyrrolo[3,4-c]pyrrol-2(1H)-yl- $N$-hydroxybutanamide (9b).

Yield: $65 \%$, white powder, $\mathrm{mp} 180-181{ }^{\circ} \mathrm{C},{ }^{1} \mathrm{H}$ NMR $(500 \mathrm{MHz}$, DMSO) $\delta: 10.37(\mathrm{~s}, 1 \mathrm{H}), 9.80-9.00(\mathrm{~d}, 1 \mathrm{H}), 8.66(\mathrm{~s}, 1 \mathrm{H}), 8.24(\mathrm{~d}$, $J=8 \mathrm{~Hz}, 2 \mathrm{H}), 7.54(\mathrm{t}, J=7.0 \mathrm{~Hz}, 2 \mathrm{H}), 7.47(\mathrm{t}, J=7 \mathrm{~Hz}, 1 \mathrm{H})$, 3.56-3.50 (m, 2H), 2.01 (t, $J=8 \mathrm{~Hz}, 2 \mathrm{H}$ ), 1.79 (q, $J=6.5 \mathrm{~Hz}$, $2 \mathrm{H}) .{ }^{13} \mathrm{C}$ NMR (125 MHz, DMSO) $\delta: 168.8,163.9,161.8,134.4$, $130.2,129.3,128.7,127.1,123.2,122.2-116.8$ (c, $J=273.75$ ), 117.0-116.0 (c, $J=42.75), 37.8,30.3,24.8$. HRMS $\left(\mathrm{EI}^{+}\right)$: calcd for $\mathrm{C}_{17} \mathrm{H}_{15} \mathrm{~F}_{3} \mathrm{~N}_{3} \mathrm{O}_{4}^{+}[\mathrm{M}+\mathrm{H}]^{+}$, 382.1015; found, 382.0961 .

6-(1,3-Dioxo)-4-phenyl-6-(trifluoromethyl)-3,5-dihydropyrrolo[3,4-c]pyrrol-2(1H)-yl- $N$-hydroxyhexanamide (9c). Yield 75\%, yellow powder, mp 95-96 $\mathrm{C},{ }^{1} \mathrm{H}$ NMR $(500 \mathrm{MHz}$, DMSO) $\delta: 10.37(\mathrm{~s}, 1 \mathrm{H}), 9.80-9.00(\mathrm{~d}, 1 \mathrm{H}), 8.66(\mathrm{~s}, 1 \mathrm{H}), 8.24(\mathrm{~d}$, $J=8 \mathrm{~Hz}, 2 \mathrm{H}), 7.54(\mathrm{t}, J=7.0 \mathrm{~Hz}, 2 \mathrm{H}), 7.47(\mathrm{t}, J=7 \mathrm{~Hz}, 1 \mathrm{H})$, 3.56-3.50 (m, 2H), 2.01 (t, $J=8 \mathrm{~Hz}, 2 \mathrm{H}), 1.79$ (q, $J=6.5 \mathrm{~Hz}$, 2H). ${ }^{13} \mathrm{C}$ NMR (125 MHz, DMSO) $\delta: 168.8,163.9,161.8,134.4$, $130.2,129.3,128.7,127.1,123.2,122.2-116.8$ (c, $J=273.75$ ), 117.0-116.0 (c, $J=42.75), 37.8,30.3,24.8$. HRMS $\left(\mathrm{EI}^{+}\right)$: calcd for $\mathrm{C}_{17} \mathrm{H}_{15} \mathrm{~F}_{3} \mathrm{~N}_{3} \mathrm{O}_{4}^{+}[\mathrm{M}+\mathrm{H}]^{+}$, 410.1328; found, 410.1350 .

\section{2 Biological assays.}

\subsubsection{Cytotoxicity assay}

The cell viability effect of SAHA against different groups of cells was determined by using the MTT dye uptake method. $2 \times 10^{3}$ cells were cultured in RPMI 1640 medium supplemented with $10 \%$ FBS in 96 well plates. SAHA and other compounds in concentrations: $1,2.5,5$, and $10 \mu \mathrm{M}$ were added and cells were incubated for 24,48 and $72 \mathrm{~h}$. Subsequently, $20 \mu \mathrm{L}$ MTT solution $(5 \mathrm{mg} / \mathrm{mL})$ was added to each well. After incubation for $4 \mathrm{~h}$ at $37^{\circ} \mathrm{C}$, the supernatant was removed and $150 \mu \mathrm{L}$ DMSO was added. When the blue crystals were dissolved, the optical density (OD) was detected by a microplater reader (Epoch Biotek). $\mathrm{IC}_{50}$ was taken as the concentration that induced $50 \%$ inhibition of cell proliferation.

\subsubsection{Western blot analysis (Histone Acetylation)}

Cell lysates were prepared by sonication in ice-cold lysis buffer containing $50 \mathrm{mM}$ Tris- $\mathrm{HCl}, \mathrm{pH} 7.8,0.25 \mathrm{M}$ sucrose and $1 \%(\mathrm{w} / \mathrm{v})$ SDS (sodium dodecyl sulfate), $1 \mu \mathrm{g} / \mathrm{ml}$ pepstatin, $10 \mu \mathrm{g} / \mathrm{ml}$ leupeptin, $2 \mathrm{mM}$ sodium orthovanate, $10 \mathrm{mM} \mathrm{NaF}, 5$ mM EDTA, $5 \mathrm{mM} N$-ethylmaleimide (NEM), $40 \mu \mathrm{g} / \mathrm{ml}$ phenylmethylsulphonyl fluoride (PMSF), and $0.1 \%$ Nonident-P40. Electrophoresis was performed on $30 \mu \mathrm{g}$ of sample proteins loaded onto $12 \%$ SDS-polyacrylamide gel. Prestained molecular- mass markers were run on adjacent lanes. The gels run in duplicate were electroblotted and stained with Coomasie blue. Blots were probed with anti-H3 acetylated primary antibodies (1:1000). Horseradish peroxidase-conjugated goat anti-rabbit $\operatorname{IgG}(1: 2000)$. Secondary IgG binding was visualized using an enhanced chemiluminescence Western blot analyzer (Amersham). Blot images were digitized (Chemidoc, Bio-Rad).

\subsubsection{Comet assay}

The comet assay protocol was modified to detect oxidized bases and to agree with the critical parameters of the proposed protocol [42]. In brief, two duplicate comet slides were made for each treatment: one slide was treated with Fpg and the other served as a control. Aliquots of $10 \mu \mathrm{l}$ with 20000 cells were mixed with $90 \mu \mathrm{l}$ of $0.7 \%$ agarose and the mixture was transferred onto a frosted slide, pre-coated with normal melting agarose (1\%). A cover slip was added, and the slide was cooled on ice to harden the agarose. For positive controls the slides were treated with $50 \mu \mathrm{l}$ of $2 \times 10^{-5} \mathrm{M}$ hydrogen peroxide for 5 minutes and then incubated at $4^{\circ} \mathrm{C}$ in fresh lysis light protected buffer $\left(2.5 \mathrm{M} \mathrm{NaCl}, 0.1 \mathrm{M} \mathrm{Na}_{2}\right.$ EDTA, $0.01 \mathrm{M}$ Tris-HCl, 10 $\%$ DMSO and $1 \%$ of Triton X-100, pH10) For enzyme treatment the slides were removed from lysis buffer and incubated with enzyme reaction buffer ( $40 \mathrm{mM}$ Hepes, $0.1 \mathrm{KCl}, 0.5 \mathrm{mM}$ EDTA and $0.2 \mathrm{mg} / \mathrm{ml} \mathrm{BSA}$, adjusted to $\mathrm{pH} 8$ with $\mathrm{KOH}$ ) for 10 minutes. Fpg enzyme (50 $\mu$ l of $1: 10^{5}$ dilution) was added to the slides and incubated $35 \mathrm{~min}$ at $37^{\circ} \mathrm{C}$. These slides were washed in enzyme reaction buffer without enzyme.

Slides with and without Fpg treatment were immersed in cold alkaline unwinding electrophoresis solution $(0.3 \mathrm{M} \mathrm{NaOH}$ and $1 \mathrm{mM} \mathrm{Na}_{2}$ EDTA in deionized water $\mathrm{pH}$ 13.5) for 30 minutes and subjected to electrophoresis for $30 \mathrm{~min}$ at $25 \mathrm{~V}$ constant voltage. All this procedure was carried out in dark. The slides were stained with DAPI and analyzed by free image analysis software (Auto Comet of Triket Corporation). The tail percentage was used as DNA damage parameter. The complete protocol for specific oxidative detection with Fpg enzymes was described in another publication [43].

\section{Acknowledgements}

MMA, MAV and JR acknowledge financial support from Consejo Nacional de Ciencia y Tecnología (CONACYT) (Research grant CB-2011/168474). LB and NZ acknowledge support from CONACYT scholarships $(265238,21211)$. KJSA acknowledges a postdoctoral scholarship from the University of Guanajuato (UG) Convocatoria de Excelencia 2015. JR and MAV gratefully acknowledge financial support from the "Convocatoria Institucional de Apoyo a la Investigación Científica 2016-2017" from the UG, projects No. 736/2016 and 811/2016, respectively. We are grateful to the Laboratorio Nacional de Caracterización de Propiedades Fisicoquímicas y Estructura Molecular (UG-UAA-CONACYT, Project: 123732) for the computing time provided. We gratefully acknowledge that cell lines used in this work were kindly donated by Dr. Carmen 
Aceves from INB- UNAM, Juriquilla. We acknowledge the technical assistance of Evelyn Flores and Nydia Hernández.

\section{References}

1. Zhu, Y.; Li, H.-F.; Lu, S.; Zheng, Y.-X.; Wu, Z.; Tang, W.-F.; Zhou, X.; Lu, T. Eur. J. Med. Chem. 2010, 45, 1777-1791.

2. Hanessian, S.; Auzzas, L.; Giannini, G.; Marzi, M.; Cabri, W.; Barbarino, M.; Vesci, L.; Pisano, C. Bioorg. Med. Chem. Lett. 2007, 17, 6261-6265.

3. Glauben, R.; Sonnenberg, E.; Zeitz, M.; Siegmund, B. Cancer Lett. 2009, 280, 154-159.

4. Marks, P. Oncogene 2007, 26, 1351-1356.

5. Botrugno, O. A.; Robert, T.; Vanoli, F.; Foiani, M.; Minucci, S. Clin. Cancer Res. 2012, 18, 2436-2442.

6. Samuni, Y.; Wink, D. A.; Krishna, M. C.; Mitchell, J. B.; Goldstein, S. Free Radic. Biol. Med. 2014, 73, 291-298.

7. Stone, H. B.; Bernhard, E. J.; Coleman, C. N.; Deye, J.; Capala, J.; Mitchell, J. B.; Brown, J. M. Transl. Oncol. 2016; 9, 46-56.

8. Butler, L. M.; Agus, D. B.; Scher, H. I.; Higgins, B.; Rose, A.; Cordon-Cardo, C.; Thaler, H. T.; Rifkind, R. A.; Marks, P. A.; Richon, V. M. Cancer Res. 2000, 60, 5165-5170.

9. Manal, M.; Chandrasekar, M.; Priya, J. G.; Nanjan, M. Bioorg. Chem. 2016, 67, 18-42.

10. Miller, T. A.; Witter, D. J.; Belvedere, S. J. Med. Chem. 2003, 46, 5097-5116.

11. Jung, M.; Brosch, G.; Kölle, D.; Scherf, H.; Gerhäuser, C.; Loidl, P. J. Med. Chem. 1999, 42, 4669-4679.

12. Whitehead, L.; Dobler, M. R.; Radetich, B.; Zhu, Y.; Atadja, P. W.; Claiborne, T.; Grob, J. E.; McRiner, A.; Pancost, M. R.; Patnaik, A. Bioorg. Med. Chem. 2011, 19, 4626-4634.

13. Khajuria, R.; Dham, S.; Kapoor, K. K. RSC Adv. 2016, 6, 37039-37066.

14. Bhardwaj, V.; Gumber, D.; Abbot, V.; Dhiman, S.; Sharma, P. RSC Adv. 2015, 5, 15233-15266.

15. Estevez, V.; Villacampa, M.; Menendez, J. C. Chem. Soc. Rev. 2010, 39, 4402-4421.

16. Hu, D. X.; Withall, D. M.; Challis, G. L.; Thomson, R. J. Chem. Rev. 2016, 116, 7818-7853.

17. Howard, J. A.; Hoy, V. J.; O’Hagan, D.; Smith, G. T. Tetrahedron 1996, 52, 12613-12622.

18. Ragno, R.; Simeoni, S.; Rotili, D.; Caroli, A.; Botta, G.; Brosch, G.; Massa, S.; Mai, A. Eur. J. Med. Chem. 2008, 43, 621-632.

19. Ontoria, J. M.; Altamura, S.; Di Marco, A.; Ferrigno, F.; Laufer, R.; Muraglia, E.; Palumbi, M. C.; Rowley, M.; Scarpelli, R.; Schultz-Fademrecht, C. J. Med. Chem. 2009, 52, 6782-6789.

20. Pham-The, H.; Casañola-Martin G.; Diéguez-Santana, K.; Nguyen-Hai, N.; Ngoc, N. T.; Vu-Duc, L.; Le-Thi-Thu, H. SAR and QSAR Environ. Res. 2017, 28, 199-220.

21. Yuriev, E.; Ramsland, P. A. J. Mol. Recognit. 2013, 26, 215-239.

22. Villaseñor-Granados, T., García, S., Vázquez, M. A., Robles, J. Theor. Chem. Acc. 2016, 135, 210.

23. Chermette, H.; J. Comput. Chem. 1999, 20, 129-154.

24. Geerlings, P.; De Proft, F.; Langenaeker, W. Chem. Rev. 2003, 103, 1793-1873.

25. Gázquez, J. L. J. Mex. Chem. Soc. 2008, 52, 3-10.
26. Liu, S. B. Acta Phys.-Chim. Sin. 2009, 25, 590-600.

27. Chattaraj, P. K., Ed., Chemical Reactivity Theory: A Density Functional View, CRC Press; Taylor \& Francis Group, LLC: Boca Raton, FL, USA, 2009.

28. Bergman, J.; Lindgren, G. Tetrahedron Lett. 1989, 34, 4597-4600.

29. Shao, Y.; Molnar, L. F.; Jung, Y.; Kussmann, J.; Ochsenfeld, C.; Brown, S. T.; Gilbert, A. T.; Slipchenko, L. V.; Levchenko, S. V.; O’Neill, D. P. Phys. Chem. Chem. Phys. 2006, 8, 3172-3191.

30. Thomsen, R.; Christensen, M. H. J. Med. Chem. 2006, 49, 3315-3321.

31. Lauffer, B. E.; Mintzer, R.; Fong, R.; Mukund, S.; Tam, C.; Zilberleyb, I.; Flicke, B.; Ritscher, A.; Fedorowicz, G.; Vallero, R. J. Biol. Chem. 2013, 288, 26926-26943.

32. Somoza, J. R.; Skene, R. J.; Katz, B. A.; Mol, C.; Ho, J. D.; Jennings, A. J.; Luong, C.; Arvai, A.; Buggy, J. J.; Chi, E. Structure 2004, 12, 1325-1334.

33. Bottomley, M. J.; Surdo, P. L.; Di Giovine, P.; Cirillo, A.; Scarpelli, R.; Ferrigno, F.; Jones, P.; Neddermann, P.; De Francesco, R.; Steinkühler, C. J. Biol. Chem. 2008, 283, 26694-26704.

34. Schuetz, A.; Min, J.; Allali-Hassani, A.; Schapira, M.; Shuen, M.; Loppnau, P.; Mazitschek, R.; Kwiatkowski, N. P.; Lewis, T. A.; Maglathin, R. L. J. Biol. Chem 2008, 283, 11355-11363.

35. Ouyang, H.; Ali, Y. O.; Ravichandran, M.; Dong, A.; Qiu, W.; MacKenzie, F.; Dhe-Paganon, S.; Arrowsmith, C. H.; Zhai, R. G. J. Biol. Chem. 2012, 287, 2317-2327.

36. Frisch, M. J.; Trucks, G. W.; Schlegel, H. B.; Scuseria, G. E.; Robb, M. A.; Cheeseman, J. R.; Scalmani, G.; Barone, V.; Mennucci, B.; Petersson, G. A.; Nakatsuji, H.; Caricato, M.; Li, X.; Hratchian, H. P.; Izmaylov, A. F.; Bloino, J.; Zheng, G.; Sonnenberg, J. L.; Hada, M.; Ehara, M.; Toyota, K.; Fukuda, R.; Hasegawa, J.; Ishida, M.; Nakajima, T.; Honda, Y.; Kitao, O.; Nakai, H.; Vreven, T.; Montgomery Jr., J. A.; Peralta, J. E.; Ogliaro, F.; Bearpark, M. J.; Heyd, J.; Brothers, E. N.; Kudin, K. N.; Staroverov, V. N.; Kobayashi, R.; Normand, J.; Raghavachari, K.; Rendell, A. P.; Burant, J. C.; Iyengar, S. S.; Tomasi, J.; Cossi, M.; Rega, N.; Millam, N. J.; Klene, M.; Knox, J. E.; Cross, J. B.; Bakken, V.; Adamo, C.; Jaramillo, J.; Gomperts, R.; Stratmann, R. E.; Yazyev, O.; Austin, A. J.; Cammi, R.; Pomelli, C.; Ochterski, J. W.; Martin, R. L.; Morokuma, K.; Zakrzewski, V. G.; Voth, G. A.; Salvador, P.; Dannenberg, J. J.; Dapprich, S.; Daniels, A. D.; Farkas, Ö.; Foresman, J. B.; Ortiz, J. V.; Cioslowski, J.; Fox, D. J. Gaussian 09, Gaussian, Inc.: Wallingford, CT, USA, 2009.

37. Parr, R. G.; Yang, W. Density-Functional Theory of Atoms and Molecules; Revised ed.; Oxford University Press New York, NY, USA, 1994.

38. Martinez-Ariza, G.; Dietrich, J.; De Moliner, F.; Hulme, C. Synlett. 2013, 24, 1801-1804.

39. Nie, J.; Guo, H. C.; Cahard, D.; Ma, J. A. Chem. Rev. 2010, 111, 455-529.

40. Wang, D.; Helquist, P.; Wiest, O. J. Org. Chem. 2007, 72, 5446-5449.

41. Lee J. H.; Choy M. L.; Ngo, L.; Foster, S. S.; Marks, P. A. Proc. Natl. Acad. Sci. 2010, 107, 14639-14644.

42. Speit, G.; Kojima, H.; Burlinson, B.; Collins, A. R.; Kasper, P.; Plappert-Helbig, U.; Uno, Y.; Vasquez, M.; Beevers, C.; De Boeck, M. Mut. Res. Genetic Toxicol. Environ. Mutagen. 2015, 783, 6-12.

43. Martinez-Alfaro, M.; Palma-Tirado, L.; Sandoval-Zapata, F.; Carabez-Trejo, A. Toxicol. Lett. 2006, 163, 198-205. 